\title{
DESAIN AKSI JEJARING KOMISI YUDISIAL DALAM MONITORING PUTUSAN TINDAK PIDANA KORUPSI DI JAWA TIMUR
}

\author{
Nunuk Nuswardani, Erma Rusdiana, Deni Setya Bagus Yuherawan \\ Fakultas Hukum Universitas Trunojoyo Madura \\ nooq.fh@gmail.com
}

\begin{abstract}
The object of this research is the implementation /action network Judicial Commission related to the handling of cases of corruption by judges in an area that has not been optimal.

This is due to the problem of monitoring the process of setting standards in the area of Corruption case management for KY's networking and the existence of the unit in action KY networks area have become the un- 'established' unit and weren't able to synergize with stakeholders. This study is an empirical law with the facts of observation methods in the study site and KY's data / case as a basis of search results in the form of 'action' which refers to the legislation in force, so that the design and methods of a blend of legal research methods and sociological research methods. The findings in this study indicate that in action, yet coordinated network of $K Y$, there is no standardization of the process of monitoring the behavior of judges in the handling of cases, and the lack of synergy between KY's networking with stakeholders.
\end{abstract}

Keywords : network, action, monitoring, unit complain, Judicial Commission

\begin{abstract}
Abstrak
Objek penelitian ini adalah pelaksanaan/aksi jejaring Komisi Yudisial terkait penanganan kasus tindak pidana korupsi oleh hakim di daerah yang selama ini belum optimal. Hal tersebut disebabkan adanya permasalahan mengenai pengaturan standarisasi proses pemantauan penanganan perkara Tipikor di daerah bagi jejaring $\mathrm{KY}$ dan mengenai keberadaan unit aksi jejaring $\mathrm{KY}$ di daerah belum menjadi unit yang 'mapan' dan mampu bersinergi dengan pihak-pihak pemangku kepentingan (stake holder). Penelitian ini merupakan penelitian hukum empiris dengan metode observasi pada fakta di lokasi penelitian dan data/perkara Tipikor yang dimiliki KY sebagai dasar pencarian hasil penelitian berupa 'tindakan/aksi' yang mengacu pada peraturan perundang-undangan yang berlaku, sehingga desain dan metodenya merupakan perpaduan antara metode penelitian hukum dan metode penelitian sosiologis. Temuan dalam penelitian ini menunjukkan bahwa dalam aksinya, jejaring KY belum terkoordinasi, belum ada standarisasi proses pemantauan perilaku Hakim dalam penanganan perkara, serta belum adanya sinergi antara jejaring KY dengan pemangku kepentingan
\end{abstract}

Kata kunci : jejaring , aksi, monitoring, unit complain, Komisi Yudisial

\section{A. Pendahuluan}

Penelitian ini dilatar-belakangi oleh kondisi saat ini bahwa matriks tingkat kepercayaan masyarakat terhadap kinerja peradilan berada pada posisi yang sangat rendah. Fenomena yang terjadi di lembaga peradilan akhir-akhir ini terutama karena seringnya muncul gejala yang menimbulkan 'tanda tanya' di Pengadilan Tindak Pidana Korupsi (selanjutnya disebut Tipikor) di daerah. Sejak terbentuknya Pengadilan Tipikor di daerah resmi diumumkan Mahkamah Agung pada 21 Oktober 2011, sampaibulan Agustus 2012,Indonesia Corruption Watch (ICW) mencatat telah ada lebih kurang 70 putusan vonis bebas terhadap terdakwakorupsi di pengadilan tipikor daerah (Tempo.Co., Politik, 2012).

Kondisi ini menjadi keprihatinan banyak kalangan, terutama kalangan masyarakat. Pendirian sejumlah pengadilan tipikor di daerah ternyata tidak memenuhiharapan dan semangat yang sama dengan pendahulunya yakni Pengadilan Tipikor Jakarta, yang dikenal sebagai kuburan para koruptor. Korupsi merupakan kejahatan yang merugikan negara dan masyarakat, namun tampaknya, korupsi hanya menjadi musuh utama masyarakat. Jalinan kerjasama antara aktor-aktor mafia politik, mafia hukum, mafia ekonomi, mafia peradilan semakin kuat sehingga dikhawatirkan melemahkan semangat pemberantasan dan perlawanan terhadap korupsi.

Berbagai keluhan masyarakat pencari keadilan tidak dapat lagi menjadi media kontrol bagi lembaga peradilan untuk melakukan perbaikan.Carut-marut kondisi peradilan yang dinilai mengandung Kolusi, Korupsi, dan Nepotisme (KKN) dan mafia peradilan menjadipenyebab utama. Masyarakat menilai bahwa pengadilan yang seharusnya menjadi tempat untuk menemukan keadilan ternyata tidak mampu memberikan keadilan bahkan terkesan mendzolimi (Anom B Prasetyo, 2012: 32). Untuk merubah 
paradigma tersebut, tidak sajamenjadi tugas Komisi Yudisial (selanjutnya disebut KY) sebagai lembaga yang mempunyai tugas menjaga dan menegakkan kehormatan, keluhuran martabat serta perilaku hakimtetapi juga harus di dukung oleh semua elemen masyarakat (Harifin Tumpa: 2010: 10 ).

Data dari KY menunjukkan bahwa untuk mengawasi sekitar 7 (tujuh) ribuan hakim di seluruh Indonesia, Komisi Yudisial (KY) sangattergantung kepada'jejaring' yang dibangun di daerah-daerah. Hal ini dikarenakan terpusatnya pengawasan bagi hakim di Jakarta, serta terbatasnya sumber daya manusia (SDM) yang dimiliki KY.Data KY tersebut juga menginformasikan bahwa ada investigator $\mathrm{KY}$, namun,investigator yang dimiliki KY pun sampai saat ini hanya berjumlah belasan orang saja.

Menyadari kekurangan ini, KY sejak 6 (enam) tahun terakhir ini telah membangun jejaring-jejaring di daerah dengan caramelibatkan masyarakat, seperti : kelompok sosial (civil society), Lembaga Swadaya Masyarakat (LSM), organisasi kemasyarakatan, perguruan tinggi dan pers.Pelibatan masyarakat tersebut dilembagakan dalam bentuk posko, dengan sebutan posko jejaring KY (Ketua KY, wawancara oktober 2012).

Di beberapa daerah telah dibentuk posko jejaring KY. Peran posko jejaring KY ini diharapkan mampu menjadi kepanjangan tangan KY di daerahdaerah dalam rangka memantau hakim-hakim, khususnya 'perilaku' para hakim pada saat menerbitkan putusannya. Kondisi keberadaan posko jejaring $\mathrm{KY}$ ini sesuai dengan keberadaan hasil kerjasama yang dijalin antara KY dan lembaga yang bersangkutan.Apabila ada kerjasama yang dilandasi kesepakatan kerjasama (MoU), maka didalamnya tertuang materi atau bidangbidangkesepakatan antara pihak KY dan pihak posko jejaring $\mathrm{KY}$.

Pada umumnya pembentukan jejaring $K Y$ ini dilandasi dengan semangat 'alturisme' atau mengedepankan kepentingan orang lain, oleh karenanya, dengan prinsip dan semangat itu, $\mathrm{KY}$ dan jejaringnya akan berada dalam satu kesepakatan bersama. Dengan prinsip dan semangat alturisme tersebut, diharapkan ada satu kesepakatan bersama yaitu problem penguatan demokratisasi dalam domain law enforcement dengan landasan prinsip kesukarelaan, kesetaraan, kebebasan, peradaban, transformasi, reformasi peradilan dan kepercayaan (Bryson, John M.,1999, lihat juga Malik, 2009, h, .23-25).

Solusi dan prinsip pembentukan jejaring $\mathrm{KY}$ ini lah yang menjadi perhatian dan pokok pembahasan saat ini, hal ini disebabkan meski telah dibentuk beberapa Posko, ternyata dalam praktek masih tidak terdengar 'kiprah'nya dalam mengawal suatu perkara. Seringkali suatu proses peradilan yang diwarnai masalah perilaku para hakim justru diungkap oleh lembaga lain di luar jejaring $\mathrm{KY}$ (misalnya oleh Indonesia Corruption Watch). Jejaring KY (khususnya di wilayah Madura) bagaimati suri, tanpa kegiatan yang berarti bagi $\mathrm{KY}$ dan kepentingan yang lebih luas bagi masyarakat, yakni keadilan.

Berdasarkan realitas empirik yang dipaparkan di atas, perlu dikaji keberadaan jejaring KY dalam memantau perkara dan perilaku hakim Tipikor (khususnya perkara tindak Pidana Korupsi)di wilayah Madura, yang permasalahannya dirumuskan sebagaiberikut:

1. Pengaturan standarisasi proses pemantauan penanganan perkara Tipikor di daerah bagi jejaring $\mathrm{KY}$

2. Keberadaan unit aksi jejaring $\mathrm{KY}$ di daerah belum menjadi unit yang 'mapan' dan mampu bersinergi dengan pihak-pihak pemangku kepentingan (stake holder)

\section{B. Metode Penelitian}

Penelitian ini merupakan penelitian hukum empiris dengan metode observasi pada fakta di lokasi penelitian dan data/perkara Tipikor yang dimiliki KY sebagai dasar pencarian hasil penelitian berupa 'tindakan/aksi' yang mengacu pada peraturan perundang-undangan yang berlaku, sehingga desain dan metodenya merupakan perpaduan antara metode penelitian hukum dan metode penelitian sosiologis.

Perspektif hukum nampak pada analisis terhadap peraturan perundangan-undangan (Peter Mahmud Marzuki, 2005: 13) yang mengatur tentang $\mathrm{KY}$ dan peran serta jejaring $\mathrm{KY}$ dalam pemantauan kinerja hakim. Dalam perspektif sosiologis maka analisis diarahkan pada hal-hal yang berkaitan dengan pembentukan model sosialyakni berupa kebijakan strategis dalam hal fungsi monitoring proses peradilan yang antara lain dengan cara melembagakan 'desain aksi' di daerah sebagai penguat fungsi kelembagaan KY. Sudah barang tentu, dalam hal ini analisis akan difokuskan bagaimana pengaturan standarisasi proses pemantauan penanganan perkara Tipikor di daerah bagi jejaring KY. Selanjutnya, standar proses pemantauan tersebut diharapkan mampu mendukung keberadaan unit aksi jejaring $\mathrm{KY}$ di daerah yang belum menjadi unit yang 'mapan' dan mampu bersinergi dengan pihak-pihak pemangku kepentingan (stake holder).

Penelitian ini dilaksanakan dengan kegiatan lapangan yang berlokasi di wilayah Madura yang penanganan perkaranya meliputi pengadilan Tindak

Desain Aksi Jejaring Komisi Yudisial... 
Pidana Korupsi (selanjutnya disebut Tipikor) Propinsi Jawa Timur di Surabaya. Adapun wilayah Maduratempat perkara Tipikor,terdiri empat Kabupaten,yaitu: Kabupaten Bangkalan, Kabupaten Sampang, Kabupaten Pamekasandan Kabupaten Sumenep.

Adapun disain untuk menemukan model lembaga jejaring KYsebagai suatu unit yang 'mapan'dituangkan dalam urutan pemikiran sebagai berikut:

1. Memberi sosialisasi pada masyarakat tentang peran serta masyarakat dalampemantauan penanganan perkara Tipikor di daerah.

2. Melakukan dialog dari seluruh unsur masyarakat khususnya para tokoh masyarakat dan tokoh agama untuk kesadaran pemantauan penanganan perkara Tipikor di daerah;

3. Mendiskusikan secara kritis hakikat dari potensi dan hambatan jejaring $\mathrm{KY}$ dalam pelaksanaan pemantauan penanganan perkara Tipikor di daerah dengan jejaring KY di Madura, LSM, akademisi, Hakim Tipikor di Surabaya;

4. Pemahaman perlunya aksi kolektif bagi pemecahan masalah pemantauan penanganan perkara Tipikor di daerah melalui pemberdayaan jejaring $\mathrm{KY}$.

5. Dengan ditemukannya model pemantauan penanganan perkara Tipikor di daerah, agar dapat mempunyai kekuatan mengikat maka perlu diatur dalam peraturan yang mampu mengatur lembaga-lembaga lintas sektoral.

Untuk memperoleh data dalam penelitian ini ditempuh dengan menggunakan data primer dan data sekunder. Sebelum dilakukannya kedua teknik pengumpulan data tersebut, terlebih dahulu dilakukan apa yang oleh Spradley (Sanapiah Faisal, 1990:54-55) dipahami sebagai 'penciptaan' (rapport) untuk meminimalisir keterasingan peneliti dengan para informan dan atau responden penelitian dan sekaligus menjajaki fisibilitas untuk dapat bekerja sama. Hal ini dianggap penting karena informan pada setiap strata dipastikan tidak dapat memberikan informasi yang lugas dan apa adanya.

Cara memperoleh data primer adalah dengan teknik wawancara mendalam (depth interview) dengan Ketua KY, hakim Tipikor, LSM, Pengacara, akademisi dan informan lainnya sesuai bidang penelitian. Sedangkan data sekunder diperoleh melalui studi dokumen.Lewat teknik wawancara, akan digali data selengkap-lengkapnya. Tidak saja tentang apa yang diketahui, apa yang dialami informan penelitian, tapi juga apa yang ada dibalik pandangan dan pendapat dari informan. Teknik wawancara yang dipakai disini adalah wawancara semi-terstruktur, yaitu berupa daftar pertanyaan mengenai pokok masalah sehingga memungkinkan adanya variasi pertanyaan yang disesuaikan dengan situasi ketika wawancara dilakukan. Sedangkan untuk mendapatkan data agar sesuai dengan diinginkan, maka pedoman wawancara dan alat bantu seperti alat perekam suara (tape recorder) dan alat foto dipersiapkan secara matang sebelum wawancara dilakukan.Sedangkan data sekunder diperoleh dari KY, Pengadilan Negeri, Pengadilan Tipikor, kantor-kantor penegak hukum (Kepolisian, Kejaksaan), dan kantor pengacara, perpustakaan, informasi media, dan lain-lain.

Data kualitatif yang dikumpulkan dalam proses pengumpulan data akan di sajikan dalam paparan (deskripsi) mendalam dan terfokus. Dalam hal ini akan dilakukan verifikasi data kualitatif yang berhubungan dengan topik penelitian.

\section{Hasil Penelitian dan Pembahasan}

1. Pengaturan Standarisasi Proses Pemantauan Penanganan Perkara Tipikor di Daerah Bagi Jejaring KY

Jejaring $\mathrm{KY}$ adalah group yang muncul ditengah masyarakat yang prihatin atas kinerja peradilan. Beberapa MoU jejaring $\mathrm{KY}$ menyatakan bahwa group ini merupakan media komunikasi dalam upaya koordinasi, elaborasi dan aksi-aksi yang bertujuan untuk membangun citra PERADILAN yang BERSIH dan BERWIBAWA. Kerjasama antara Komisi Yudisial Indonesia dengan masyarakat dari berbagai elemen ini berupaya membantu penguatan demokrasi dalam bidangpenegakan hukum dengan landasan prinsip kesukarelaan, kesetaraan, kebebasan, peradaban, transformasi, reformasi peradilan dan kepercayaan. Meskipun materi kesepakatan kerjasama jejaring KY telah dicantumkan secara lengkap, namun, dalam pelaksanaannya, pemantauan proses peradilan oleh jejaring $\mathrm{KY}$ ini masih menemui banyak kendala, terutama dalam hal kelembagaan dan inter-koneksi nya dengan masyarakat dan KY.Atas dasar hal-hal tersebut maka penelitian ini memiliki tujuan khusus untuk melembagakantugas dan fungsi jejaring KY sebagai pemantauan peradilan di daerah secara mapan sehingga akan mempermudah inter-koneksi dengan KY dan meningkatkan efisiensi dalam pemberian solusi yang tepat guna bagi masyarakat pencari keadilan.

Berbagai media memberitakan bahwa saat ini di dunia peradilan di Indonesia terdapat fenomena tentang korupsi peradilan (judicial corruption) dalambentuk berbagai perilaku tercela (permainan kotor) seperti penyuapan, transaksiperkara, calo perkara, makelar kasus 
(sering disebut 'Markus'), pemerasan, jual beli putusan, dansebagainya.Isu korupsi peradilan itu terkait adanya fenomena tentang makelar kasus (markus), rekayasa kasus, penyuapankepada aparat penegak hukum (polisi, jaksa, panitera, dan hakim) oleh pihapihak tertentu, pemerasan yang dilakukanoleh aparat penegak hukum dalam menangani kasus hukum dsb. Hal tersebut menjadi nyata setelah diputarnyarekaman hasil penyadapan KPK terhadap Anggodo Widjojo dalam Sidang Mahkamah Konstitusi dalam Kasus BibitChandra tanggal 3 Nopember 2009.(M. Syamsudin, Jurnal Hukum no. edisi khusus vol. 18 oktober 2011 , h : 127 - 145)

Keadilan dalam suatu proses peradilan mutlak perlu. Khususnya dalam peradilan Tipikor yang merugikan negara dan masyarakat. Semakin berkualitas putusan yang dihasilkan oleh Hakim, semakin berkualitas pulakeadilan yang diperoleh masyarakat, serta semakin berkualitas pula peran lembaga yang terlibat di dalamnya. Kualitas putusan peradilan dapat dicapai apabila Hakim yang membuat putusan adalah Hakim yang berkualitas. Hakim yang berkualitas sangat sulit 'dibentuk', tapi kualitas Hakim dapat ditemukan sejak saat rekrutmen Hakim dilaksanakan oleh KY.

Keberadaan KY menimbulkan pembaharuan rekrutmen hakim agung dan dalam penegakan wibawa lembaga peradilan. Peran KY sangat strategis, mengingat lembaga peradilan di Indonesia selama ini telah menuai kritik dan ketidak-percayaan masyarakat yang mengandung tuduhan terjadinya 'ketidakadilan' (in justice) putusan, adanya 'mafia peradilan' kepada seluruh jajaran hakim di semua lini peradilan (dari Pengadilan Tingkat Pertama, Pengadilan Tingkat Banding sampai Mahkamah Agung).

Kritik dan tuduhan tersebut bukan tidak berdasar. Beberapa Lembaga Swadaya Masyarakat (LSM) seperti Indonesian Corruption Watch (ICW) telah membeberkan hasil monitoring peradilan yang dilakukannya pada bulan Juni 2001 di media tentang terungkapnya kasus pro-judicial corruption yang dilakukan oleh pihak-pihak yang beracara di lembaga peradilan, baik pengacara, polisi, jaksa, termasuk juga, hakim. Transparency International Indonesia (TII, Februari 2009) telah mengemukakan hasil penelitian Indeks Persepsi Suap dan Korupsi yang juga menunjukkan keterlibatan lembaga peradilan (termasuk hakim) dengan indeks dan nominal suap yang lebih tinggi dibandingkan lembaga lainnya.Berbagai kasus hukum yang terbongkar di pengadilan, seperti : penyuapan, pemerasan dan kolusi semuanya melibatkan hakim (termasuk hakim agung). Penelitian dari lembaga independen seperti LSM dan kasus lainnya yang tidak mengemuka, menunjukkan bahwa ketidak-adilan putusan sebagai akibat keterlibatan hakim pada kasus suap mengakibatkan citra buruk lembaga peradilan hingga saat ini belum juga hilang.

Untuk mencapai suatu standar keadilan dalam memutus suatu perkara di persidangan tidaklah mudah.Sudikno Mertokusumo menyatakan bahwa keadilan adalah bentuk spesifik dari keunggulan (specific form of exellence)yang selalu dipertalikan dengan hukum, sifat 'adil' dan 'tidak adil' selalu dilekatkan pada Hakim, pemeriksaan pengadilan dan putusan sidang pengadilan. Dalam suatu putusan wajib ada secara proporsional:kepastian hukum (rechtssicherheit); kemanfaatan (zweckmassigkeit); keadilan(gerechtigkeit)'. Kalau dalam pilihan putusan sampai terjadi konflik antara keadilan dan kepastian hukum, maka keadilan yang harus didahulukan (Sudikno Mertokusumo, 2003: 26).

Mengenai 'keadilan', dapatdikutip pendapat H.L.A.Hartyang menyatakanbahwa:

' ....justice is traditionally thought of as maintaining or restoring a balance or proportion, and its leading precept is often formulated as 'treat like cases alike'; though we need to add to the latter and treat different cases differently'.(Hart,H.L.A., 1961, p.26, The Liang Gie, 1982).

[keadilan lazimnya dipikirkan sebagai pemeliharaan atau pemulihan suatu keseimbangan atau perimbangan, dan ajarannya yang terkenal sering dirumuskan sebagai 'perlakukanlah peristiwa-peristiwa yang sama secara sama' ; meskipun kita perlu menambahkan 'dan perlakukanlah peristiwaperistiwa yang berbeda secara berbeda'].

Merujuk pada pendapat tersebut, dapat diartikan bahwa persoalan keadilan yang tidak diperoleh pihak yang dirugikan pada suatu sengketa,merupakan'ketidak-seimbangan perlakuan' sehingga mengakibatkan kepentingannya tidak terlindungi.

Sejalan dengan pendapat H.L.A Hart tentang ketidak-seimbangan perlakuan tersebut, dapat dikemukakan pendapat Sudikno Mertokusumo yang menyatakan bahwa :

Desain Aksi Jejaring Komisi Yudisial... 
"Kaidah hukum lazimnya diartikan sebagai peraturan hidup yang menentukan bagaimana manusia itu seyogyanya berperilaku, bersikap di dalam masyarakat agar kepentingannya dan kepentingan orang lain terlindungi...."(Sudikno Mertokusumo, 2003: 26).

Kaidah hukum atau sering disebut norma hukum tersebut merupakan pedoman berperilaku bagi manusia agar kepentingan semua pihak terlindungi. Selanjutnya dinyatakan bahwa:

"Fungsi kaidah hukum pada hakekatnya adalah untuk melindungi kepentingan manusia dan tujuan kaidah hukum adalah ketertiban masyarakat. Kalau kepentingan manusia terlindungi, maka keadaan masyarakat akan tertib. Kaidah hukum bertugas mengusahakan keseimbangan tatanan di dalam masyarakat dan kepastian hukum agar tujuannya tercapai, yaitu ketertiban masyarakat"(Sudikno Mertokusumo, 2003: 27).

Berdasarkan kutipan-kutipan tersebut di atas, fungsi kaidah hukum menurut Sudiknohampir sama dengan konsep keadilan menurut Hart, yakni sebagai penjaga keseimbangan tatanan di dalam masyarakat dan kepastian hukum. Dengan demikian dapat diartikan, "keadilan tercapai apabila terjadi keseimbangan perlakuan dan kepentingan semua pihak dilindungi".

Perwujudan keadilan dalam putusan Pengadilan dapat tercapai apabila terjadi sinergitas antara Hakim yang berperan sebagai "sarana perubah/agent of change" keadaan, (dengan cara melakukan terobosan pengambilan putusan yang disertai pertimbangan cermat), dan didukung oleh "Lembaga pendukung Peradilan" seperti KY, yang diharapkan memiliki dan menerapkan langkah-langkah strategis pembinaan kinerja menuju lembaga peradilan yang modern dan terpercaya. Demikian pula dalam rangka kewenangan $\mathrm{KY}$ untuk perekrutan hakim agung, akan memudahkan kinerja KY dalam penegakan kehormatan hakim jika yang direkrut adalah hakim agung yang berkualitas, profesional dan berkepribadian baik. Kemudahan pemantauan oleh KY tersebut secara tidak langsung akan menurun pada jejaringnya.

Namun kenyataannya,pada setiap perekrutan tidak selalu didapathakim yang berkualitas, profesional dan berkepribadian baik. Fakta menunjukkan semakin maraknya persoalan yang terkait perilaku hakim yang menyimpang dari kewenangan yang diberikan kepadanya. Oleh karenanya, diperlukan kinerja $\mathrm{KY}$ yang maksimal. Dengan strategisnya fungsi $K Y$ tersebut, sudah saatnya dilakukan penguatan terhadap KY agar dapatsemakin dirasakan konstribusi serta manfaatnya bagi masyarakat, bangsa dan negara.

KYsebagai lembaga negara yang hanya berada dipusat pemerintahan sangat kesulitan melaksanakan tugas dan fungsinya untuk pemantauan proses peradilan yang menjangkau daerah-daerah di Indonesia. Mengingat jalur investigasi terkendala oleh sumber daya dan fasilitas KY yang terbatas, untuk itu partisipasi masyarakat dalam melakukan pengawasan terhadap aparat penegak hukum khususnya hakim peradilan Tipikor, merupakan suatu langkah yang sangat strategis. Salah satu langkah yang konkritnya adalah melakukan kegiatan investigasi/aksi pemantauanoleh jejaring KYterhadap perilaku hakim pembuat putusan khususnya putusan terhadap tindak pidana korupsi.

Investigasi $\mathrm{KY}$ dalam menelusuri pelanggaran kode etik dan pedoman perilaku hakim, tidak jauh berbeda dengan pola-pola investigasi pers dalam mengumpulkan informasi. Hasil investigasi itu juga dituangkan dalam berita/laporan(Sutoyo, Buletin Komisi Yudisial Vol.III No.4, Jakarta, Februari 2009). KY melaksanakan tugasnya terutama tugas pengawasan berpedoman pada UU Nomor 18 Tahun 2011 tentang KY. Aturan ini merupakan perubahan UU Nomor 22 Tahun 2004 tentang KY.

Kemiripan pengaturan tentang tata cara investigasi antara KY dengan Pers tersebut ada pada Pasal 1 ayat (1) UU tentang Pers :

'....Perusahaan pers adalah lembaga sosial dan wahana komunikasi massa yang dalam kegiatan jurnalistik meliputi mencari, memperoleh, memiliki, menyimpan, mengolah dan menyampaikan informasi baik dalam bentuk tulisan gambar dan sebagainya'.

Sedangkan substansi pengaturan yang sama bagi KY ada dalam Pasal 20 ayat 1 huruf a UU Nomor 22 Tahun 2004, tentang pelaksanaan pemantauan dan pengawasan terhadap hakim. Selanjutnya pengaturan mekanisme proses pemantauan perilaku hakim oleh KY dalam Pasal 20 ayat 1 :

a. huruf b UU Nomor 22 Tahun 2004:"laporan itu diterima dari masyarakat",

b. huruf c, dilakukan: "verifikasi", "klarifikasi", serta "investigasi" ditambah dalam UU Nomor 18 Tahun 2011 yang baru tentang $\mathrm{KY}$.

Desain Aksi Jejaring Komisi Yudisial... 
Dengan demikian, sebelum suatu investigasi dilakukan, terdapat proses "prainvestigasi"yang terdiri tahapan: penerimaan laporan masyarakat dan atau informasi lainnya (termasuk berita dari media massa), yang kemudian didiskusikan dalam sidang panel (untuk membahas laporan/informasi yang masuk), setelah itu dilanjutkan sidang pleno(seluruh personel komisi/komisioner), yang kemudian berdasarkan sidang pleno tersebut terbit surat perintah dari kepala bidang pengawasan hakim (kabid waskim) untuk pelaksanaan investigasi, dan atas dasar surat perintah investigasi tersebut dapat dilakukan investigasi.

Dalam pelaksanaannya, sebelum memulai investigasi, semua harus berangkat dari asas praduga tak bersalah. Di dalam tahap sidang panel dan sidan pleno dilakukan "analisa sasaran" atas laporan masyarakat atau berita dari media massa, setelah itu, bersiap turun ke lapangan. Persiapan ini merupakan persiapan perencanaan yang matang. Ini dilakukan untuk mengumpulkan bukti-bukti pendukung dan mengolah data-data tersebut menjadi laporan.

Dalam konteks pelaksanaan tahapantahapan kegiatan investigasi oleh $\mathrm{KY}$ tersebut diperlukan dukungan jejaring KY.Jejaring KY inidiharapkan dalam pelaksanaannya mampu meningkatkan partisipasi atau peran serta masyarakat dalam rangka pengawasan dan pembenahan sistem manajemen dan administrasi peradilan secara terpadu. Melaluiaksi jejaring KY yang dirancang secara baik diharapkan bisa merangkul masyarakat sipil dan lembaga swadaya masyarakat (LSM) dan lembaga lainnya dalam membantu sosialisasi $\mathrm{KY}$ kepadamasyarakat.Dengan demikian, urgensi penelitian jejaring $\mathrm{KY}$ ini sangat mendesak karena berkaitan dengan rasa keadilan masyarakat.

Mengenai kinerja jejaring KY dalam praktekdi Pengadilan Tipikor (dalam hal ini Pengadilan Tipikor Surabaya),karena telah dibentukPosko jejaring KY, maka telah ada/ dilakukanpemantauan terhadap perilaku hakim pada proses persidangan Tipikor. Posko jejaring $\mathrm{KY}$ diharapkan mempermudah akses masyarakat yang ingin mengadu ke KY. Pada awal terbentuknya di tahun 2011, ada 18 posko percobaan (pilot project), di tahun 2012 akan ditambah lagi 9 Posko. Dengan adanya Posko ini, diharapkan KY terbantu dalam melaksanakan pemantauan perilaku dalam kinerja Hakim dan Pengadilan, serta menerima laporan pengaduan (wawancara Ketua KY, Oktober 2012).

Posko pemantauan hasil MoU dengan masyarakat juga diharapkan oleh KY bisa difungsikan sebagai wadah untuk mensinergikan $\mathrm{KY}$ dengan pemangku kepentingan lainnya, seperti LSM, Rumah Aspirasi bentukan Dewan Perwakilan Daerah (DPD). Namun kenyataannya, hasil penelitian menunjukkan bahwa banyak aduan masyarakat mengenai kekurang-puasan terhadap kinerja dan perilaku Hakim dan atau lembaga Peradilan yang masuk ke rumah aspirasi DPD.

Aksi jejaring $\mathrm{KY}$ ini tidak dapat dilepaskan dari peran serta masyarakat dalam membasmi korupsi, karena jejaring $\mathrm{KY}$ adalah bagian dari masyarakat di lingkungannya. Peran-serta masyarakat dalam memberantas korupsi diatur dalam Pasal 41 UU No.31 Tahun 1999 Tentang Pemberantasan Tindak Pidana Korupsi, dengan substansi sebagai berikut:

(1) Masyarakat dapatberperan serta membantu upaya pencegahan dan pemberantasan tindak pidana korupsi.

(2) Peran serta masyarakat sebagaimana dimaksud dalam ayat (1) diwujudkan dalam bentuk :

a. hak mencari, memperoleh, dan memberikan informasi adanya dugaan telah terjadi tindak pidana korupsi;

b. hak untuk memperoleh pelayanan dalam mencari, memperoleh dan memberikan informasi adanya dugaan telah terjadi tindak pidana korupsi kepada penegak hukum yang menangani perkara tindak pidana korupsi;

c. hak menyampaikan saran dan pendapat secara bertanggung jawab kepada penegak hukum yang menangani perkara tindak pidana korupsi;

d. hak untuk memperoleh jawaban atas pertanyaan tentang laporannya yang diberikan kepada penegak hukum dalam waktu paling lama 30 (tiga puluh) hari;

e. hak untuk memperoleh perlindungan hukum dalam hal : 
melaksanakan haknya sebagaimana dimaksud dalam huruf a, b, dan c; diminta hadir dalam proses penyelidikan, penyidikan, dan di sidang pengadilan sebagai saksi pelapor, saksi, atau saksi ahli, sesuai dengan ketentuan peraturan perundangundangan yang berlaku;

(3) Masyarakat sebagaimana dimaksud dalam ayat (1) mempunyai hak dan tanggung jawab dalam upaya pencegahan dan pemberantasan tindak pidana korupsi.

(4) Hak dan tanggung jawab sebagaimana dimaksud dalam ayat (2) dan ayat (3) dilaksanakan dengan berpegang teguh pada asas-asas atau ketentuan yang diatur dalam peraturan perundangundangan yang berlaku dan dengan menaati norma agama dan norma sosial lainnya.

(5) Ketentuan mengenai tata cara pelaksanaan peran serta masyarakat dalam pencegahan dan pemberantasan tindak pidana korupsi sebagaimana dimaksud dalam Pasal ini, diatur lebih lanjut dengan Peraturan Pemerintah.

Secara khusus Pasal 41 ayat (2) huruf b yang menyatakan bahwa peran serta masyarakat sebagaimana dimaksud dalam ayat (1) diwujudkan dalam bentuk : hak untuk memperoleh pelayanan dalam mencari, memperoleh dan memberikan informasi adanya dugaan telah terjadi tindak pidana korupsi kepada penegak hukum yang menangani perkara tindak pidana korupsi; dari sinilah masyarakat sebagai peran serta masyarakat dalam mengawal proses tipikor mulai berjalan, dan secara khusus jejaring Komisi Yudisial mengambil peran dalam memantau penanganan perkara tipikor di daerah khususnya terhadap putusan tipikor.

Peran serta masyarakat dalam pemberantasan korupsi ini selanjutnya diatur melalui Peraturan Pemerintah (PP) No. 71 tahun 2000 tentang Tata Cara Pelaksanaan Peran Serta Masyarakat dan Pemberian Penghargaan dalam Pencegahan dan Pemberantasan Tindak Pidana Korupsi. Dalam pengaturan PP tersebut, 'peran serta masyarakat'dalam Pencegahan dan Pemberantasan Tindak Pidana Korupsi diartikan sebagai peran aktif organisasi masyarakat, perorangan, atau LSM dalam pencegahan dan pemberantasan tindak pidana korupsi.
Alasan utama bagi terwujudnya (raison d'etre) KY didalam suatu negara hukum, adalah:

(1) Komisi Yudisial dibentuk agar dapat melakukan monitoring yang intensif terhadap kekuasaan kehakiman dengan melibatkan unsur-unsur masyarakat dalam spectrum yang seluas-luasnya dan bukan hanya monitoring secara internal,

(2) Komisi Yudisial menjadi perantara (mediator) atau penghubung antara kekuasaan pemerintah (executive power) dan kekuasaan kehakiman (judicial power) yang tujuan utamanya adalah untuk menjamin kemandirian kekuasaan kehakiman dari pengaruh kekuasaan apapun juga khususnya kekuasaan pemerintah,

(3) Dengan adanya Komisi Yudisial, tingkat efisiensi dan efektivitas kekuasaan kehakiman (judicial power) akan semakin tinggi dalam banyak hal, baik yang menyangkut rekruitmen dan monitoring hakim agung maupun pengelolaan keuangan kekuasaan kehakiman,

(4) Terjaganya konsistensi putusan lembaga peradilan, karena setiap putusan memperoleh penilaian dan pengawasan yang ketat dari sebuah lembaga khusus (Komisi Yudisial),

(5) Dengan adanya Komisi Yudisial, kemandirian kekuasaan kehakiman (judicial power) dapat terus terjaga, karena politisasi terhadap perekrutan hakim agung dapat diminimalisasi dengan adanya Komisi Yudisial yang bukan merupakan lembaga politik, sehingga diasumsikan tidak mempunyai kepentingan politik (Buku saku Sosialisasi Komisi Yudisial, 2009).

Secara kelembagaan KYberkedudukan di Jakarta sebagai ibukota negara, dengan wewenang dan tugasnya menjangkau seluruh Indonesia. Untuk mewujudkan salah satu alasan utama terbentuknya $\mathrm{KY}$ yaitu agar dapat melakukan monitoring yang intensif terhadap kekuasaan kehakiman adalah dengan cara melibatkan unsur-unsur masyarakat dalam spektrum yang seluas-luasnya dan bukan hanya monitoring secara internal.

Salah satu hal yang dapat mendukung adalah melalui penguatan institusional KY. Namun, penguatan itu saja tidak cukup,KY perlu dukungan dengan carabekerjasama dan bersinergi dengan masyarakat. Melalui 
pembentukan jejaring $\mathrm{KY}$ diharapkan masyarakat dapat berperan secara aktif berpartisipasi mendukung KY dalam rangka perang terhadap mafia peradilan yang saat ini semakin merajalela di dunia Peradilan.

Elemen masyarakat mestinya dapat dilibatkan sebagai kepanjangan tangan KY dalam melaksanakan pemantauan/investigasi. Jaringan kerja jejaring KY ini dapat meliputi :Perguruan Tinggi, Non Governmental Organization (NGO) atau Lembaga Swadaya Masyarakat (LSM), Organisasi Masyarakat (Ormas), dan Organisasi Kemasyarakatan dan Pemuda (OKP) serta Pers.

Partisipasi masyarakat dalam melakukan pengawasan terhadap aparat penegak hukum khususnya hakim, merupakan suatu langkah yang sangat strategis. Langkah yang dilakukan oleh jejaring KYdalammelakukan kegiatan pengawalan terhadap proses hukum pada prinsipnya dapat di mulai dari tahap penyidikan hingga putusan pengadilan. Dengan demikian rangkaian proses dapat terangkai dengan baik dan informasi yang di peroleh lebih komprehensif.

Hal ini perlu karena saat ini semakin banyak keluhan masyarakat pencari keadilan tentang kinerja penegak hukum yang tidak tersalurkan. Bahkan media massa seolah-olah tidak dapat lagi menjadi media kontrol bagi lembaga peradilan untuk melakukan perbaikan. Timbul kesan bahwa pengadilan yang seharusnya menjadi benteng terakhir untuk melawan ketidakadilan ternyata tidak berbuat apa-apa bahkan terkesan sangat jauh dari tujuannya yaitu untuk memberikan keadilan.

Dalam hal keluhan masyarakat terhadap mafia peradilan, contohnya adalah putusan Pengadilan Negeri (PN) Surabaya No.46/EKS/ 2006/PN Sby jp. No.191/Pdt.G/2006/PN Sby antaraPT Rahmad Bakti melawan Moeksaid Suparman tentang surat tanah Pethok $D$, yang ternyata eksekusinya di lokasi tanah bersertifikat milik PT Cinderella. Substansi putusan PN Surabaya yang memenangkan jenis surat tanah petok $D$ terhadap tanah bersertifikat sungguh merupakan putusan yang luar biasa menyimpang. Indikasi bahwa putusan tersebut telah direkayasa tampak sangat jelas.Bukti kuat penyimpangan ada di masyarakat,namun, masyarakat pencari keadilan ini tidak tahu kemana melaporkan perilaku Hakim yang menyimpang tersebut.Ketika diinformasikan ada jejaring KY yang bisa menampung danmeneruskan laporan ke KY, masyarakat menyatakan tidak tahu.
Berkaitan dengan rasa keadilan masyarakat pencari keadilan,keberadaan hakim merupakan salah satu aspek yang sangat penting dalam rangkaian proses penegakan hukum. Hakim bertugas untuk memeriksa dan memutus suatu perkara yang dapat menentukan nasib seseorang.Dengan tugas tersebut, bahkan Hakim sering disebut sebagai wakil Tuhan di dunia. Oleh karenanya, disamping harus selalu ada pengawasan untuk meluruskan niat Hakim, dari diri Hakim itu sendiri juga harus muncul sikap adil yang mutlak diperlukan dalam penanganan perkara.

Meskipun upaya pemberantasan tindak pidana korupsi merupakan bagian dari upaya menciptakan tata pemerintahan yang baik (good governance), namun tidak berarti upaya penegakan hukumnya dapat di'sub-ordinasi' oleh aspek politik dan Pemerintah. Semua pilar-pilar yang terkait dengan upaya dan proses penegakan hukum harus menopang dan memperkuat sehingga korupsi dapat ditekan ketitik yang dapat dikendalikan.

Dengan demikian, proses penegakan hukum merupakan rangkaian panjang dan saling terkait antar aspek yang saling mempengaruhi dalam upaya pemberantasan tindak pidana korupsi. Pemerintah jangan sampai kehilangan dukungan dari masyarakat akibat ketidakseriusannya memberantas tindak pidana korupsi. Masyarakat dan aparat penegak hukum merupakan ujung tombak yang keberadaannya saling melengkapi satu sama lain.

Masyarakat yang dapat mengambil berperan dalam mengontrol, karenanya masyarakat harus diberi ruang dan kesempatan luas untuk berpartisipasi melalui sistem dan tatanan yang demokratis dan transparan. Meskipun aspek pemberdayaan itu sangat penting dalam proses dan strategi pemberantasan tindak pidana korupsi, namun itu semua harus dilakukan dalam batas-batas dan koridor hukum yang berlaku.

Bentuk dan sifat partisipasi masyarakat dalam proses tersebut harus diselenggarakan secara demokratis dalam susunan yang menghargai nilai-nilai (norma) dan rasa kepatuhan serta keadilan, tanpa harus mengabaikan perlindungan dan penghargaan terhadap hak-hak asasi manusia ${ }^{1}$.

Dari hasil penelitian yang telah dilakukan di empat (empat) Kabupaten di Madura yaitu Kabupaten Bangkalan, Sampang, Pamekasan dan Sumenep di peroleh informasi bahwa 
sampai saat ini di Madura,organisasi yang aktif berperan serta dalam kegiatan monitoring ini diantaranya organisasi intern kampus seperti Unit Pendidikan, Konsultasi dan Bantuan Hukum (UPKBH) Fakultas Hukum Univer sitas Trunojoyo, kegiatan ekstern mahasiswa di Madura misalnya GMNI, HMI dan PMII. Adapun LSM yang aktif melalukan monitoring yaitu LIRA (lumbung informasi Rakyat) di Bangkalan, Madura Development watch (MDW) di Sampang dan Pamekasan, Jawa Timur Coruption watch (JCW) di Sumenep. Mereka yang berperan serta inilah yang dapat disebut sebagai jejaring KY.Baldassari dan Diani (2007) dalam Aris Purnomo 2011, mendefinisikan jaringan kerja kelompok sebagai jaringan dari kolaborasi dan keanggotaan yang bersinergi antar organisasi yang berkolaborasi yang secara formal independen dan terpisah dari negara, yang bertindak secara kolektif dan untuk kepentingan publik.

Oleh karena belum ada standarisasi prosedur kinerja jejaring KY,maka data menunjukkan bahwa semua responden penelitian ini bekerja menurut model, tata caradan kinerja masing-masing. Peran serta masyarakat di 4 kabupaten diatas di lakukan melalui kegiatan-kegiatan yang seringkali sifatnya 'spontan', yaitu kegiatan tersebut dilakukan secara langsung dan terbuka oleh sekelompok orang berkaitan dengan upaya penanggulangan korupsi. Contohnya: unjuk rasa, mendatangi lembaga pemerintahan yang dituduh melakukan korupsi, dan demonstrasi ke lembaga ke penegak hukum (kepolisian, kejaksaan dan pengadilan) agar serius menangani suatu kasus korupsi.

Namuncara unjuk rasa ini pun tidak banyak dilakukan oleh LSMyang concern dibidang penanggulangan korupsi. LSM penggiat anti korupsi ini sering melakukan kegiatan yang sifatnya 'tidak langsung'.LSM tersebut aktif melakukan kegiatan-kegiatan yang berintikan upaya menanggulangi korupsi, seperti melaporkan adanya tindak pidana korupsi oleh seorang pejabat di suatu instansi, memberikan masukan dan kritik terhadap penggunaan anggaran dan laporan dugaan korupsi suatu instansi, dan lain-lain.

Aktivitas monitoring yang dilakukan merupakan bentuk kepedulian dan ke'tidakpuas'an terhadap penegakan hukum perkaraTipikor. Informasi yang diperoleh dari ketua Jawa Timur Corruption Watch (JCW) yang berkedudukan di Sumenep yaitu Bp. Zajali , untuk mendapatkan data-data tentang kasus yang mereka sorot tidaklah mudah karena terkait dengan sistem, ancaman pihak yang disorot, dan mahalnya informasi (karena informasi secara rinci harus diperoleh dengan cara membeli).

Saat ini aktivitas monitoring oleh jejaring $\mathrm{KY}$ ini masih terbatas pada pencarian datadata/ bukti pendukung yang harus mereka siapkan terkait suatu kasus, pemantauan hanya sampai di tingkat penyidikan dan sampai berkas perkara dinyatakan P 21 (sempurna) oleh Kejaksaan Negeri . Setelah memasuki tahap persidangan mereka yang semula mengawal kasus tersebut biasanya menghentikan aktivitasnya.

Secara kelembagaan jejaring KY yang ada di Madura belum terkoordinir dengan baik, bahkan belum pernah mendapat pembinaan dari $\mathrm{KY}$, sehingga belum ada standarisasi pembentukan jejaring maupun teknis pelaksanaannya. Pada akhirnya aktivitas monitoring yang dilakukan oleh kelompok yang dapat dikatagorikan jejaring KY tersebut seolah tidak terkoordinasi dan tidak terukur. Dengan demikian dukungan jaringan kerja ini tidak optimal ketika kemampuan dan penguatan jaringan kerja tidak dilakukan sesuai kebutuhan dan tidak juga dikembangkan oleh KY sebagai kepanjangan tangannya.

Di seluruh Indonesia, sampai saat ini,Komisi Yudisial telah membentuk jejaring di 30 provinsi, yangsekaligus berfungsi sebagai proses pen'demokratisasi'an praktek penegakan hukum di seluruh Indonesia, yang selama ini sulit dijangkau oleh tangan-tangan demokrasi (http://www.komisiyudisial.go.id/ berita-1517-jejaring-untuk-membantumasyarakat-html). Kinerja jejaring KY tersebut akan lebih optimal hasilnya apabila ada standarisasi koordinasi dan aktivitas kinerjanya.

2. Jejaring KY Di Daerah Belum Menjadi Unit Yang 'Mapan' Dan Mampu Bersinergi Dengan Pihak-Pihak Pemangku Kepentingan (Stake Holder)

Hasil penelitian yang telah dilakukan di empat (empat) Kabupaten di Madura yaitu Kabupaten Bangkalan, Sampang, Pamekasan dan Sumenep di peroleh informasi bahwa sampai saat ini di Madura belum terbentuk jejaring KYsebagai unityang'mapan' dan mampu bersinergi dengan stakeholder.KY yang berkedudukan di Jakarta dengan wilayah kewenangannya meliputi seluruh Indonesia 
tidak akan dapat menjalankan fungsi dan perannya tanpa melakukan kerja sama dengan masyarakat.

Memiliki jejaring sebagai kepanjangan tangan merupakan kebutuhan KY untuk kepentingan penguatan peran pengawasan hakim.Hubungan KY dengan jejaring akan memperkuat eksistensi kelembagaan. Untuk itu diperlukan bentuk jejaring yang mapan dan bersinergi dengan pemangku kepentingan agar dapat tercipta tujuan terbentuknya jejaring dapat tercapai. Jejaring yang mapan adalah jejaring yang jelas keberadaannya.

Pelaksanaan investigasi terhadap suatu laporan penyimpangan perilaku hakim saat pengambilan putusan yang dilakukan secara transparan akan membuat Hakim yang sedang menangani perkara lebih berhati-hati. Informasi dari seorang Ketua Majelis Hakim dalam satu perkara Tipikor di pengadilan Tipikor Surabaya menyatakan bahwa sampai saat ini tidak pernah ada pemantauan secara 'terbuka' oleh jejaring KY. Kalau dengar-dengar info katanya memang ada jejaring $K Y$ yang ikuti persidangan Tipikor secara diam-diam. Tata cara pemantauan perkara tidak transparan oleh jejaring $\mathrm{KY}$ tersebut berbeda dengan jejaring Komisi Pemberantasan Korupsi (KPK) yang secara jelas mengungkap kehadirannya di persidangan (mengajukan ijin ke Ketua Pengadilan), membawa kamera di ruang sidang, orang-orang yang hadir memantau persidangan diberi identitas, sehingga jelas para pemantau tersebut berasal dari KPK. Dengan identitas jelas tersebut pemantau persidangan dari KPK diberi kesempatan tanya-jawab dengan majelis hakim seusai persidangan, sehingga diperoleh laporan akurat dari berbagai sisi, yaitu sisi pemantau persidangan perkara korupsi dan pemantau kepentingan lainnya.

Pembentukan kerjasama dengan KY untuk wilayah Madura telah ada, yaitu antara lain kerjasama dengan Fakultas Hukum Universitas Trunojoyo Madura (FH UTM). Namun, hingga penelitian ini dilakukan, kerjasama dalam bentuk MoU antara KY-FH UTM tersebutbelum tampak kinerjanya, dan belum berjalan sebagaimana mestinya untuk merangkul masyarakat, LSM dan atau lembaga lainnya dalam membantu KY sebagai jejaring. Saat ini aktivitas jejaring yang ada tidak terkoordinasi dan berjalan atas model, tata cara, kemampuan dan karakter kinerja masing-masing lembaga.
Padahal sebagai mitra yang sangat potensial sebagai kepanjangan tangan $\mathrm{KY}$ selayaknya jejaring ini mendapat dukungan, berupa pembinaan dan informasi yang cukup tentang strategi dan program-program Komisi Yudisial, atau dapat juga dijadikan sebagai posko jejaring KY (koordinator wilayah Madura). Pemanfaatan potensi jejaring ini belum maksimal. Walaupun sesungguhnya peran yang dilakukan KY memberikan ruang kepada lembaga non pemerintah dan masyarakat untuk berperan serta secara optimal dalam pengawasan hakim dan peran lain dalam mewujudkan 'peradilan bersih dan berwibawa' sangat memungkinkan adanya sinergi kekuatan elemen masyarakat sipil seperti kampus dengan LSM, ormas atau OKP, dan pers.

Data dari anggota salah satu LSM menyatakanbahwa keberadaan jejaring kadangkala dimanfaatkan oleh oknum tertentu (elit organisasi) untuk memperoleh keuntungan pribadi, bahkan diboncengi kepentingan politik hingga menjadikan anggota jejaring bersikap sangat aktif pada penanganan kasus korupsi tertentu, namun apatis terhadap kasus korupsi lainnya.Untuk itu sangatlah penting adanya koordinasi, baik antara Posko dengan jejaring maupun antar jejaring, untuk mengantisipasi agar tidak disalah gunakan oleh pihak pihak yang tidak bertanggungjawab.

Meskipun upaya pemberantasan tindak pidana korupsi merupakan bagian dari upaya menciptakan tata pemerintahan yang baik, namun tidak berarti upaya penegakan hukumnya dapat di"sub-ordinasi" oleh aspek politik dan ke-pemerintahan-an. Semua pilarpilar yang terkait dengan upaya dan proses penegakan hukum harus mendukung dan memperkuat upaya pemberantasan korupsi, sehingga korupsi dapat ditekan ketitik yang terendah.

Dengan demikian proses penegakan hukum merupakan rangkaian panjang dan saling terkait antar aspek yang saling mempengaruhi dalam upaya pemberantasan tindak pidana korupsi. Untuk kesinambungan program pemberantasan korupsi, Pemerintah harus terus memantau agar jangan sampai kehilangan dukungan dari masyarakat akibat ke'tidak-serius'annya memberantas tindak pidana korupsi.

Adapun gambaran permasalahan dan solusi bagijejaring KY di Madura yang ditemukan dalam penelitian ini adalah sebagai berikut: 


\begin{tabular}{|c|c|c|}
\hline \multicolumn{3}{|c|}{ PERMASALAHAN DAN SOLUSI JEJARING KOMISI YUDISIAL DI MADURA } \\
\hline No & Permasalahan & Solusi \\
\hline 1 & $\begin{array}{l}\text { Komisi Yudisial berada di } \\
\text { ibukota negara }\end{array}$ & $\begin{array}{l}\text { a. Jejaring KY dapat menjadi kepanjangan tangan } \\
\text { KY dalam melakukan pengawasan eksternal ter- } \\
\text { hadap perilaku Hakim dalam penanganan } \\
\text { perkara } \\
\text { b. - revitalisasi MoU antara KY dengan lembaga } \\
\text { jejaring nya }\end{array}$ \\
\hline 2 & Belum terkoordinasi & $\begin{array}{l}\text { a. Bentuk Posko Jejaring KY dan zoning Posko } \\
\text { Jejaring KY } \\
\text { b. Tunjuk salah satu Jejaring KY seba-gai } \\
\text { koordinator Posko di masing-masing zona } \\
\text { c. - Melakukan upaya koordinasi antar jejaring di } \\
\text { Madura melalui FH UTM yang telah menjalin } \\
\text { kerjasama dengan KY }\end{array}$ \\
\hline 3 & $\begin{array}{l}\text { Belum ada standarisasi proses } \\
\text { peman-tauan perilaku Hakim } \\
\text { dalam penanganan perkara }\end{array}$ & $\begin{array}{l}\text { KY segera terbitkanStandar prosedur pemantauan } \\
\text { perilaku Hakim dalam penanganan perkara, sehingga } \\
\text { pemantauan yang dilakukan oleh jejaringnya dapat } \\
\text { terukur. }\end{array}$ \\
\hline 4 & $\begin{array}{l}\text { Belum bersinergi dengan } \\
\text { pemangku kepentingan }\end{array}$ & $\begin{array}{l}\text { a. Melakukan sosialisasi jejaring KY agar } \\
\text { jejaring KY lebih di kenal dan diakses oleh } \\
\text { masyarakat pencari keadilan. } \\
\text { b. Pembinaan secara berkala dan periodik bagi } \\
\text { jejaring } \mathrm{KY} \\
\text { c. -Sharing info antar jejaring } \mathrm{KY} \text { melalui } \\
\text { bulletin/jurnal } \mathrm{KY} \text { atau fasilitas } \mathrm{KY} \text { lainnya } \\
\text { d. -Agenda kegiatan bersama secara terstruktur } \\
\text { dan periodik per wilayah pemangkuan jejaring } \\
\mathrm{KY} \text { (per Posko) }\end{array}$ \\
\hline
\end{tabular}

Dalam penelitian ini juga ditemukan proses pra-investigasi dilakukan oleh KY. Proses pra-investigasi tersebut di mulai dari :

1. Adanya laporan masyarakat atau berita di media massa tentang adanya penyim pangan perilaku Hakim pada penanganan perkara tipikor;

2. Berdasarkan laporan tersebut di lakukan sidang panel komisioner;

3. Selanjutnya dilakukan sidang pleno;

4. Berdasarkan hasil sidang pleno tersebut di terbitkan surat perintah investigasi oleh Kepala Bidang Pengawasan Hakim (Kabiswaskim);

5. Pelaksanaan Investigasi.

Jika pengaturan tentang langkah-langkah pelaksanaan pemantauan dan pengawasan terhadap Hakim secara internalKY ada standart operating prosedur (SOP)nya, maka bagaimana dengan pelaksanaan pemantauan (investigasi) oleh jejaring KY? Akankah jejaring KY dibiarkan melakukan pemantauan tanpa prosedur yang jelas?
Selama ini, karena belum ada SOP dalam melakukan monitoring perilaku Hakim dalam penanganan perkara Tipikor(khusus nya dalam perkara korupsi sesuai tema penelitian), maka hal ini menimbulkan ekses sebagai berikut :

1. Tata cara pemantauan dan perolehan bukti-bukti penyimpangan perilaku Hakim diperoleh jejaring Komisi Yudisial dengan cara yang tidak jelas parameternya.

2. Keberadaan jejaring Komisi Yudisial tidak di kenal oleh masyarakat luas sebagai pemangku kepentingan, sehingga kurang di rasakan manfaatnya oleh masyarakat (khususnya pencari keadilan).

\section{Simpulan}

Jejaring KYyang telah ada dapat dikoordinir dengan baik jika posko jejaring dapat bersinergi dengan lembaga lain yang di anggap memiliki kapasitas dan kredibilitas dalam masyarakat. Dalam keterbatasannya (baik pendanaan maupun fasilitas) harus terus ditumbuhkan inisiatif dengan sumber daya yang telah ada untuk melakukan pembinaan agar kegiatan monitoring yang dilakukan lebih terarah dan mencapai tujuan yang di harapkan. 
Langkah strategis yang dapat dilakukan KYadalah :

1. Sosialisasikeberadaan jejaring : yang mempunyai peranan penting untuk menumbuhkan dan mengembangkan kesadaran masyarakat terhadap suatu isu. Karena kesadaran masyarakat tidak muncul dengan sendirinya tetapi harus dibangun. Untuk membangun gerakan pengawasan kekuasaan kehakiman maka harus diciptakan terlebih dulu kesempatan dan pemahaman kepada masyarakat tentang manfaat jejaring. Adanya sosialisasi oleh jejaring dan pelatihan terhadap masyarakat atau pencari keadilan akan mendorong munculnya kesadaran.

2. Penguatan yang diperoleh $\mathrm{KY}$ adalah masyarakat akan saling mendukung kinerja KY dimana dukungan dan dorongan masyarakat akan semakin kuat dalam menciptakan kemandirian baik KY maupun pengadilan.

3. Revitalisasi kerjasama. Bahwa peran penguatan Komisi Yudisial dalam pengawasan hakim dapt diperoleh melalui kerja sama dengan jejaring sehingga semakin tercipta kepercayaan masyarakat kepada KY karena laporan yang dikirimkan adalah benar-benar datangnya dari masyarakat dan ditindaklanjuti dengan benar dan cepat. Kerjasama dengan jejaring yang berjalan baikakan berdampak balik kepada KY. Semakin banyak jejaring yang terlibat dalam pengawasan hakim semakin memudahkan Anggota Komisi Yudisial menjalankan tugasnya.
4. Pendirian Posko pemantauansebagai koordinator di wilayahnya juga diharapkan segera terealisasi. Posko pemantauan dapat difungsikan untuk mensinergikan $\mathrm{KY}$ dengan Rumah Aspirasi bentukan DPD. Hal tersebut, sejalan dengan latar belakang pembentukan posko, yakni mempermudah akses masyarakat yang ingin mengadu ke $\mathrm{KY}$

\section{E. Saran}

Berdasarkan hasil-hasil penelitian tersebut, maka desain aksi jejaring KY yang di usulkan dalam penelitian ini adalah dibuatnya (diatur) prosedurstandar kinerja jejaring $\mathrm{KY}$ sebagaimana prosedur investigasi bagi KY, antara lain sebagai berikut :

1. Menampung data jejaring $\mathrm{KY}$, laporan masyarakat dan/atau berita di media massa tentang adanya penyimpanganperilaku Hakim pada penanganan perkara tipikor.

2. Berdasarkan laporan tersebut di lakukan sidang panel komisioner KY.

3. Selanjutnya dilakukan sidang pleno $\mathrm{KY}$

4. Berdasarkan hasil sidang pleno tersebut di terbitkan surat perintah investigasi oleh Kepala Bidang Pengawasan Hakim (Kabidwaskim).

5. Pelaksanaan Investigasi yang'dapat'melibatkan (mengikutsertakan) jejaring KY. Kata 'dapat' dalam disain ini dimaksudkan jejaring bisa terlibat atau tidak, tergantung kesediaan dari jejaring $\mathrm{KY}$.

Dengan melibatkan jejaring dalam proses investigasi diharapkan dapat diperoleh informasi dan/ atau bukti yang lebih akurat karena data tersebut berawal dari jejaring Komisi Yudisial itu sendiri. 


\section{DAFTAR PUSTAKA}

Anom B Prasetyo. 2012. "Musim Gugur Pengadilan Tipikor", e-news Kompas.com, 27 April 2012

Buku saku Sosialisasi Komisi Yudisial, 2009

Harifin, Tumpa. 2010. Konferensi Regional Asosiasi Internasional Administrator Pengadilan (IACA)" Pendapat disampaikan dalam pidato pembukaan "di Istana Bogor, Jawa Barat

H.L.A Hart. 1961. The Concept of Law. Oxford: Clarendon Press

John M Bryson. 1999.Strategic Planning for Public and Nonprofit Organizations, A Guide Strengthening and Sustaining Organizational Achievement. Minnesota: Remdec.

M. Syamsudin. Jurnal Hukum no. edisi khusus vol. 18 oktober 2011

Peter Mahmud Marzuki. 2005. “Penelitian Hukum”. Jakarta: Prenada Media

Sanapiah.Faisal. 1990. Penelitian Kualitatif (Dasar-dasar Aplikatif): Malang: Yayasan Asih Asah Asuh

Sudikno Mertokusumo. 2003. Penemuan Hukum sebuah pengantar. Yogyakarta: Liberty

Tempo.Co. Politik. 2012, “ Pengadilan Anti Korupsi Daerah Bebaskan 70 Koruptor”, 10 Agustus 2012

The Liang Gie. 1982. Teori-teori Keadilan. Yogyakarta: Supersukses

http://ikbal13.wordpress.com, 8 Februari 2009,Peran Serta Masyarakat Dalam Pemberantasan Korupsi 